\title{
WOMEN IN THE "KERANGKENG" OF TRADITION: THE STUDY ON THE STATUS OF WOMEN IN MINANGKABAU
}

\author{
Welhendri Azwar \\ Universitas Islam Negeri (UIN) Imam Bonjol Padang \\ email : welhendriazwar@uinib.ac.id
}

Received: 21 May 2017. Accepted: 19 October 2017

Published: November 2017

\begin{abstract}
The system of values, norms and some stereotypes attached to women are one of the factors that giving influences on the position and relationships of women with men in the existing social structure. Each person embraces the system of values or norm which is a consensus and constructed by the community itself than from generation to generation. The emergence of social construction on the status and role of women is the result of the perspective of a community towards their biological differences between men and women. The perspective which then results in oppression, exploitation, and subordination of women in social relations are contextually strongly related to socio-cultural conditions at that time. This section will discuss how women are positioned in the social life and the perspective of the culture of its subordination. Next, it is also described how the emergence of patriarchal ideology, a system that accommodates the interests of men to dominate and control women, as a consequence of the understanding of the nature of women which biologically different to men. The hegemony of patriarchal ideology brings the social awareness for women to accept the conditions of subordination as a natural thing, which is wrapped by the products of culture and tradition. It includes how patriarchal ideology is giving the effect on the system and the tradition of marriage.
\end{abstract}

Keywords: The status of women; patriarchy, 'kerangkeng' of tradition, Minangkabau. 


\section{Introduction}

\section{Women in a cultural perspective}

Cultural understanding concerning the issues of women, the status and role in social life varied in accordance with the development of the situation and time. It also depends on how these understandings relating to the position of women in various communities. Even anthropologists who are investigating the position of women in the development of society unconsciously involved in the debate concerning the origin and universality of the marginalization of women. Thus we study the hierarchical relationship between men and women as an important thing.

Men and women which are naturally, biologically and genetically different is a fact as the nature of God that cannot be changed. However, there is a debate when the differences in this nature lead to varied understandings of in each person and in the community. This different understanding is known as the concept of gender which is several characteristics attached to the men and women who are socially and culturally constructed ${ }^{1}$. For example, the stereotype of women is known as gentle, maternal, emotional or more patient. While men are considered strong, rational, etc. brave. These stereotypes can be exchanged and may be different in each community, depending on the culture and value systems are built.

It is started from certain understandings of the biological differences between men and women that are socialized in quite a long time, leading to the formation of a value system. The value system became pattern, guidance, and even tied the people in the act on the social process. The

\footnotetext{
${ }^{1}$ Mansoer Fakih, Analisis Gender Dan Tranformasi Sosial (Yogyakarta: Pustaka Pelajar, 1997).

Jurnal Pengembangan Masyarakat Islam
} 
value systems form a particular culture in giving position and role in the social life of women in society.

Fundamentally, the existence of gender differences which subsequently results in gender role is based on the biological differences between men and women, in fact, it is not a problem, and it does not need to be sued. If women with reproductive organs can naturally be pregnant, delivery a baby and do breastfeeding, and then have gender roles as nurses, caregivers, and educators, it is a matter of nature, natural. The problem is the gender roles of women are valued and appreciated much lower than the gender roles of the male. Gender role can result in injustice, discrimination, and oppression to the women. It basically is a socially constructed which means an image built by a particular community, as it has been explained, through a very long social process that is socialized even strengthened by the legitimacy of the cultural values and religion.

\section{Patriarchy: A hegemonic ideology}

In the history of the development of society matrilineal system changes with power pattern matriarchal to the patriarchal, patrilineal system, it does not just happen. On the other side, it contains certain interests, including the interests of the community of men to control and dominate the economic assets that that have resulted. These interests further are institutionalized in the form of social systems or cultures. A social system that gives power to men is then known by patriarchal ideology.

Ideology as the knowledge that is actualized in the form of action, which has been interfered with by the feelings, interests and other subjective factors ${ }^{2}$. Ideological knowledge is the knowledge that is not absolute and universal

${ }^{2}$ Karl Mannheim, Ideologi Dan Utopia (Yogyakarta: Kanisius, 1991). 
anymore because of the subjective nature. Therefore, in the process of interaction in social life, ideology is defined as a system built to justify or legitimize the oppression of a community by another community.

The question that then arises is why women easily want to be exploited. Even now there are various protest movements and resistances, why so many women are willing to accept even tend to maintain a system that manifestly oppresses them.

Supremacy of a social class obtained in two ways; first is through domination or coercion, and the second is through intellectual and moral leadership ${ }^{3}$. Departing from this premise, the marginalization of women can be explained. First, when the division of work is getting sharpened between public and domestic area, men increasingly dominate and control of economic assets, and women are increasingly confined to domestic life. Finally, women are increasingly economically dependent on men. Men become the leader of the family, which is hidden behind an interest to control and master the economic assets which they fought. The pattern of family leadership further manifested in social life, where men have always been dominant in every aspect of life, political, cultural and legal. At this moment the dominant and oppressive patriarchal ideology results in the political product, the value system, the legal system in favor of the interests of men. There is a value system that gives the position to the man as head of household, while a woman as a housekeeper is an example. This system is obviously forcing women to be the servant of men.

Second, the dominance of men in the public world resulting in the products of culture, law, and politics that are institutionalized through social institutions eventually forms

\footnotetext{
${ }^{3}$ Nezar Patria and Andi Arief, Antonio Gramsci, Negara Dan Hegemoni (Yogyakarta: Pustaka Pelajar, 1999).

Jurnal Pengembangan Masyarakat Islam
} 
the apparent awareness of women to obey. For this condition, the material situation determines the social, political and intellectual processes. This means that the existence and social position of women determine the awareness of social roles. Women willingly accept the position of subordination and even tend to forget it. Oppression is not considered as the issue. Thus, the oppression is not considered as oppression, even considered as nature. This condition is by Gramsci called hegemony.

Hegemony is a condition of supremacy acquired through intellectual and moral leadership ${ }^{4}$. According to Gramsci, hegemony is a chain of victories obtained through a consensus mechanism that fosters awareness through existing institutions in society. The patriarchal ideology is a system that manifesting through social, political and economic institutions. The system is built for the benefit of man, and therefore it is the basis of the oppression of women.

As a small community, the family institution is seen as the most patriarchal institution. In the family, institution found a hierarchical system where men are positioned higher and powerful, while women are lower and to be ruled. The family is an important institution for educating and transforming the patriarchal values. Within families that individuals obtain a lesson about hierarchy, subordination, and discrimination. Where boys learn force and power, otherwise the women learn how to observe, learn treated unequally and learn to socialize themselves with people who are marginalized. Instead of imprisonment in the circle of the household activity is used as an instrument to measure happiness by women.

In a long historical way, the hegemony of patriarchal ideology successfully built the awareness of the ethical

\footnotetext{
${ }^{4}$ Patria and Arief.
} 
position of women in social roles. In Indonesia for example, from the research results, there is a tendency that there is no correlation between happiness and wife with the husband's participation in helping housework, particularly in Java families. Even at Minahasa family, the correlation tends to be negative where the higher the level of participation of the husband in doing housework, the lower the level wife's happiness. Found that in the Java family, the husband is expected to deal with matters outside the household ${ }^{5}$. Wife's devotion to her husband for the Java community is viewed as sacred. It is even considered as the happiness when the wife could devote herself and her lives to her husband. Wife's devotion is regarded as a source the happiness in marriage.

This reality morally shows that men dominate and control women. Women in this condition are in an alienated position because all the activities of their lives are just as completeness for others ${ }^{6}$. Before marrying a woman is much more regulated by parents and when married her parents handed their daughter to her husband. The woman later belongs to her husband, taking care of her husband and the household, and when she becomes a mother, she begins to become the maid of her children. A woman becomes alienated, according to Foreman, because life is always intended for to the interests of others, to be part of another person, so that she loses her true identity.

What is understood experienced or becomes the moral consciousness of women about the status and social role is a socially constructed system of values, norms and social ethics. This building then becomes an ideology in the process of

\footnotetext{
${ }^{5}$ Ratna Megawangi, Membiarkan Berbeda, Sudut Pandang Baru Tentang Relasi Gender (Bandung: Mizan, 1999).

${ }^{6}$ Anne Foreman, Femininity as Allienation: Women and The Family in Marxism and Psichoanalisis (London: Pluto Press, 1997).
}

Jurnal Pengembangan Masyarakat Islam 
interaction, and transformed from generation to generation through the existing social institutions, for example, the family institution. So since little, kids are already burdened with normative rules, where the appropriate thing is done by men and which are worth is doing by women. Normative rules are slowly shaping attitudes and individual character in playing the social role. This shows that patriarchal ideology will extend its hegemony against women. The position of women is increasingly permanent as kanca wing king, as a companion of men behind the lines and burdened with the obligation of taking care the household.

\section{Women In Minangkabau Custom}

Talking about women is not never ceased, this topic always interesting to discuss, especially in the country women (Minangkabau) ${ }^{7}$. In the matrilineal family structure of Minangkabau, women occupy a central position and importance. Women in Minangkabau terminology is also called as bundo landing, the title that is always used to refer to married women. The title of bundo landing refers to the maternal traits that have leadership insights because she is a descendant successor. Correspondingly with that, she was required to be able to form patterns of thought and human nature in continuing survival of generation.

In the philosophy of Minangkabau custom, bundo kanduang is a milestone in the household and pillar of nagari. In her hands, it relies on a good or bad direction of household life and society in general. Thus bundo kanduang has a social function as the primary educator of noble character.

The figure of bundo kanduang is depicted in the proverbial:

\footnotetext{
${ }^{7}$ Mery Kurnia, 'Buruh Perempuan Di Negeri Perempuan : Studi Kasus Pergeseran Peran Perempuan Minangkabau', 7.1 (2017), 57-66.
} 


\section{Bundo kanduang}

\section{Limpapeh rumah nan gadang}

\section{Sumarak dalam nagari}

\section{Hiyasan dalam kampuang}

\section{Umbun puro pagangan kunci}

There are two things that can be captured from the narrative of the proverbial above. First, Minangkabau women play a role in maintaining lineage because of its matrilineal system and as a custodian of the treasures of communal ownership in the inheritance system. Second, the feminine aspect is a very important criteria in judging the figure of Minangkabau women. Women are only positioned as an object, a complement to the social life, and a decoration in hometown.

This means that women structurally have a very central and fundamental position in the social systems of Minangkabau. On the other hand in social relationships, they have no formal position. Minangkabau woman is simply a manifestation of the potential social rights (public life) played by men. Existence herself as a citizen is immersed. This is where the contradiction on the figures of women Minangkabau between the right and the high position with the freedom of self-actualization in social relations.

The ideal social function of the woman is depicted in traditional philosophy which is often faced with the reality. Women are often positioned as second class citizens and marginalized groups. Women are not valued as individuals who have the same potential as men, and therefore they socially do not have an equal position and equal treatment. Indeed, the normative rules of custom, women are positioned in a strategically important position as a consequence of the application of the matrilineal system. But then the position and role are strategically important that becomes diminished 
by various internal and external factors, even from women themselves. The interpretation of the customs community towards the customary rules is an example.

Minangkabau traditional system that provides that the family with all the problems and affairs become a shared responsibility under the coordination of a mamak, which is the central figure in the extended family. Anything that will be done by family members, customarily, must get the blessing of the mamak, which then must be approved by the datuk (Penghulu of the tribe).

Kamanakan barajo ka mamak.

Mamak barajo ka panghulu

Including in matters of marriage, mamak and Penghulu (datuk) should know about it and give the permission. Because all that relates to the bond of marriage is a matter for mamak, ranging from the process of proposal ceremony to the end of the wedding ceremony.

The weak position of women on this tradition is based on the mindset of traditional philosophy of gender-biased and highly patriarchal. The traditional philosophy that was born in the division of domestic-public labor is very sharp. Indeed, at that time the woman was only in charge at home, taking care of the household. Consequently, it was born the terminology "urang rumab" to call a wife. Even if there is a traditional village women who come to work in the fields or trade, it is seen as an attempt to help in alleviating the burden on the husband, to help the basic tasks of husband. This means that men are positioned as a potential dominant economic asset.

The views of male dominance to the economical values give the implications on transactions, bargaining, in the process of marriage. The problem does not lie in who 
propose and who is proposed, who pays and who is paid. The problem is on the basis and thinking patterns so that it results in the tradition of marriage that requires women propose and pay while men are proposed and are paid.

This traditional way of thinking enables the women like the queen bee which only in charge to produce offspring that are not in power in his own house. While the male role as workers and regulator of the rhythm and dynamics of the household.

At first glance, women look like liberated from heavy tasks, but the social reality they are not appreciated as an independent individual who has the right to socialize and actualize their own potential. On the other hand, men are free to mobilize, socialize and employ themselves in social relations widely

In contrast to the patriarchal system that is commonly understood, that the male power played by the father as the head of the family that controls, masters and inherits the inheritance patrilineally. While on matrilineal-patriarchal Minangkabau system, the power of men is played by mamak in the extended family (relatives) and not by the husband in the nuclear family. Concerning about inheritance, the power is only limited to control inheritance, but do not own or inherit it.

\begin{tabular}{|l|l|}
\hline \multicolumn{1}{|c|}{ The patriarchy (general) } & \multicolumn{1}{c|}{$\begin{array}{c}\text { The patriarchy } \\
\text { (Minangkabau) }\end{array}$} \\
\hline $\begin{array}{l}\text { 1. The power of men in the } \\
\text { family is as a husband. }\end{array}$ & $\begin{array}{l}\text { The power of men in the kin } \\
\text { family is by mamak. }\end{array}$ \\
$\begin{array}{l}\text { 2. Men control and dominate } \\
\text { the inheritance. }\end{array}$ & $\begin{array}{l}\text { Men only have the right to } \\
\text { control and does not inherit the } \\
\text { 3. The power of men } \\
\text { individually (husband) in } \\
\text { the family. }\end{array}$ \\
& $\begin{array}{l}\text { inheritance. } \\
\text { The power of men collectively } \\
\text { (mamak) in relatives. }\end{array}$ \\
\hline
\end{tabular}

Jurnal Pengembangan Masyarakat Islam 
It has been a shift of family forms and patterns of power in the modern family in Minangkabau ${ }^{8}$. In the kinship system of Minangkabau, there is a change from the form of extended family to the form of nuclear family. However, it does not automatically liberate women from male domination. Even women are increasingly oppressed by two forces (double power) at the same time, which are the rule of the husband as head of household and the power of mamak in the relationship of relatives.

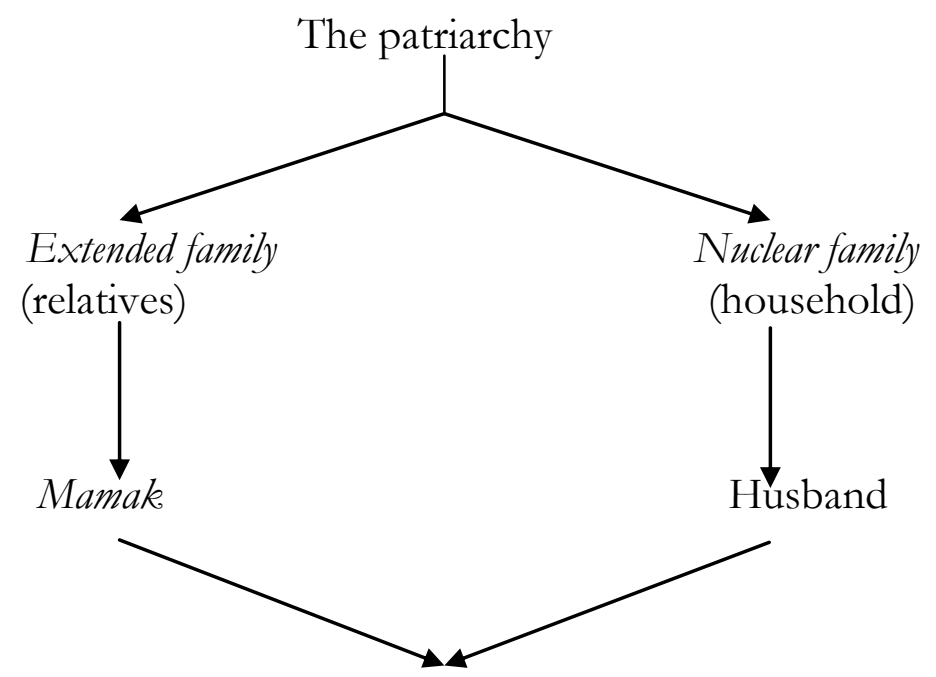

Woman

The ongoing hegemony of patriarchal politic is manifested in bajapuike tradition seen in women's attitudes to accept this as a fairness treatment, the nature of women. The

\footnotetext{
${ }^{8}$ Syafri Sairin, Beberapa Catatan Tentang Perubahan Kebudayaan Minangkabau, Dalam Mestika Zed (Ed). Perubahan Sosial Di Minangkabau: Implikasi Kelembagaan Dalam Pembangunan Sumatera Barat (Padang: PSPPSB Universitas Andalas, 1992).
}

Jurnal Pengembangan Masyarakat Islam 
emergence of awareness among women in seeing themselves is associated with the position and social treatment that are constructed for them. The process of gender inequalities that they experience is seen as a feminine nature.

To view the status of women in the family, some indicators are used, which are; first is the allocation of power in the husband-wife relationship, the husband remains as a key figure in making a decision. A decision that will be made by the wife must have permission from the husband due to the husband's perception of the head of the family. The power pattern on two families is greatly influenced by control of accessing or contributing to the family economy.

Second is the work division in the household. In this case, the woman is given the responsibility in managing the household, raising children and so on. While men earn a living. Indeed there has been a division of work between husband and wife, but the division of work still sees women as domestic workers. The division of work is not based on equal participation of men and women, husbands mop the floor and wives wash clothes for example. Alternatively, vice versa. This means that the responsibility in completing household tasks is the responsibility of the husband and wife, each of them is put in charge. However, this equality is difficult, in fact, it is almost never found because culturally it is still considered inappropriate. The pattern of work division on the household like this causes women increasingly exploited in the husband-wife relationship.

Third is, job opportunities for women is very low, including an appreciation of the work values. The view that the main occupation of women as wives that are taking care of the household greatly affect the job opportunities for women. Wife is very difficult to get permission from her husband to work outside home as an independent individual. Wife is only allowed to work merely helping her husband in the family in fulfilling the family needs, not as a career or profession. The husband is more likely, which is legitimized 
by the culture, to position the wife as a housewife, while he makes a living. At first glance, it looks like the woman is alleviated with the task of earning a living. However, the consequences are; women are increasingly dependent economically on their husbands, and thus the power of husband are not increasingly counterbalanced.

Fourth is the possession of the property. In customary law of Minangkabau, the property has been classified into two groups, namely the property of pusaka Tinggi (tambilang ruyuang) and the property of pusaka rendah (tambilang ameh). The property of pusaka tinggi is a property inherited from generation to generation in a matrilineal way. This means that property becomes the property of the women's maternal lineage. While the property of pusaka rendah is a property inherited from the mother and father as a result of their efforts in a husband-wife relationship. This peoperty is inherited to the children. Associated with the mastery of the property of pusaka tinggi is under control of mamak as the central figure in the extended family. Women are just as the owner. While the property of pusaka rendah, the management is in the hand of the husband as paterfamilias. It is also strongly associated with the pattern of husband-wife relationship in the family. If divorce happens, the property of pusaka rendah belongs to the wife, because in Minangkabau customary systems, husband "turun" from his wife's house without bringing anything. However, as a widow, the woman who had divorced her husband becomes the "burden" and the responsibility of relatives, especially mamak. That way she comes back into the extended family as well as its position before marriage. Likewise, the property left by husbands became the responsibilities of mamak to take care of. This means that women can not arbitrarily sell or pawn the property without the permission of mamak, except for its utilization. 
Simply stated, the status of women in husband-wife relationships in the family can be seen in the following table:

\begin{tabular}{|c|c|}
\hline Indicator & Reality \\
\hline $\begin{array}{ll}\text { 1. Allocation of the power } \\
\text { 2. Division of work } \\
\text { 3. Job opportunities } \\
\text { 4. } \text { Mastery of the property }\end{array}$ & $\begin{array}{l}\text { Husband domination } \\
\text { Unbalanced } \\
\text { Low } \\
\text { Husband and or mamak }\end{array}$ \\
\hline
\end{tabular}

On the other hand, the Minangkabau custom on the kinship system of its matrilineal-matrilocal is capable of being adhesive of the kinship between relatives members in accordance with the roles and respective functions. A sense of togetherness and a spirit of mutual cooperation in the communal system are based on the blood kinship and based on the principles of exchange. The idea that whenever we have " baban barek.", whatever it is, it must be shared with, barek sapikua - ringan sa jinjiang. Therefore, on this side, the Minangkabau custom gives constructive and functional impact. However, in another view, from a gender perspective, in some cases it results destructive, discriminatory and oppressive of women's rights.

\section{Conclusion}

Thus I end this discussion that women who are in the order of Minangkabau culture and custom will be able to return to their position and role, if they have a strong desire to return as well. Moreover, it is the duty of all members of society, especially Minang women to reinvigorate its traditional values that have been distorted by a variety of interests and backgrounds.

The biological differences between men and women become the basis of the emergence of an understanding of the different roles and work areas between men and women.

Jurnal Pengembangan Masyarakat Islam 
The man is on the public working area and woman is on the domestic working area. In this position, biological reality is interpreted culturally, which in turn gave birth to the normative rules that are constructed and disseminated in social relations, which are appropriate and inappropriate done by men or women. The implication is that the women increasingly stuck in the routine of household work (housewifization) and socially subordinate. Consequently, men become dominant and take control of women's lives. The domination of men in the world of public resulted in the emergence of cultural products that are institutionalized through social institutions. Thus, it starts occurring the patriarchal hegemony in social life, which then raises awareness of women to accept their oppression as "nature". This is one of the characteristics of the patriarchal system works.

In Minangkabau, the process of subordinating the women can be seen from several indicators. First, their access to the decision making. The domination of men in this context is represented by the mamak in the extended family. Second, the management or the utiliation of finance. Women do not have full authority to manage and control the assets that have been appointed for to them. Due to the utilization of economic assets should have the permission of others (mamak or husband). Third, the respect for women's social status. The social role of women is considered as a secondary role. While their basic tasks are still regarded as housewives, maid of husband, and make others happy. Fourth, the social status of women in the household. This can be seen in the allocation of power and decision-making in the household, division of work, employment and control of assets, all of which are dominated by men. Either it is by the husband in the nuclear family, or by mamak in the extended family. Minangkabau custom, on this side, actually does not make women, at least, equal to men in family relationships. As a 
person who has an access to the economy, women still are in a weak position and controlled.

Those four indicators, at least give a picture of the status of women as a subordinated community, dominated and controlled by men. Therefore, Minangkabau custom is loaded with hegemonic patriarchal ideology. The patriarchal ideology becomes culturally institutionalized and forcing people, especially women to accept the condition subordination as a reality. This proves that the patriarchal system becomes institutionalized in customary institutions. It means that on the side in, it turns out the patriarchy manifests in matrilineal-matrilocal kinship system. Where women have a double subordination, controlled by double power at the same time, which are by mamak in the extended family and by husband in the nuclear family.

\section{References}

Fakih, Mansoer, Analisis Gender Dan Tranformasi Sosial (Yogyakarta: Pustaka Pelajar, 1997)

Foreman, Anne, Femininity as Allienation: Women and The Family in Marxism and Psichoanalisis (London: Pluto Press, 1997)

Kurnia, Mery, 'Buruh Perempuan Di Negeri Perempuan : Studi Kasus Pergeseran Peran Perempuan Minangkabau', 7 (2017), 57-66

Mannheim, Karl, Ideologi Dan Utopia (Yogyakarta: Kanisius, 1991)

Megawangi, Ratna, Membiarkan Berbeda, Sudut Pandang Baru Tentang Relasi Gender (Bandung: Mizan, 1999)

Patria, Nezar, and Andi Arief, Antonio Gramsci, Negara Dan Hegemoni (Yogyakarta: Pustaka Pelajar, 1999)

Sairin, Syafri, Beberapa Catatan Tentang Perubahan Kebudayaan Minangkabau, Dalam Mestika Zed (Ed). Perubahan Sosial Di 
Women In The .... (Welhendri Azwar) 385

Minangkabau: Implikasi Kelembagaan Dalam Pembangunan

Sumatera Barat (Padang: PSPPSB Universitas Andalas, 1992) 